\title{
Picocyanobacterial community structure and space-time dynamics in the subalpine Lake Maggiore (N. Italy)
}

\author{
Cristiana CALLIERI, ${ }^{*}$ Emanuele CARAVATI, Gianluca CORNO, and Roberto BERTONI \\ CNR - Institute of Ecosystem Study, Largo V. Tonolli 50, 28922 Verbania, Italy \\ *Corresponding author: c.callieri@ise.cnr.it
}

\begin{abstract}
We investigated the community structure of freshwater picocyanobacteria (Pcy) in the oligotrophic subalpine Lake Maggiore (Northern Italy) using the least conserved sequences of the Internal Transcribed Spacer (ITS-1) fragment. The aim was to characterize the succession of Pcy Operational Taxonomic Units (OTUs) during a seasonal cycle at two environmental niches with distinctive light, temperature and mixing characteristics. ITS fragment length outlined a succession of OTUs from spring to summer, even in the absence of a pronounced spring peak. The vertical partitioning of Pcy OTUs down the water column, more evident in summer, indicates different community composition at the two depths. Redundancy Data Analysis (RDA) was carried out using temperature, pH and depth of mixing layer $\left(Z_{m}\right)$, which passed the Monte Carlo test $(p<0.05)$. A correlation between axis 1 and temperature, $p H$ and $Z_{m}$ of respectively 0.85 , 0.64 and 0.61 was found. Our results indicate that lake thermal structure, defined by temperature and $Z_{m}$, has a significant influence on the succession of Pcy OTUs and on their dynamics in colonizing different ecological niches in the vertical gradient.
\end{abstract}

Key words: picocyanobacterial diversity, oligotrophic lake, Synechococcus, ARISA, OTU.

Received: October 2011. Accepted: December 2011

\section{INTRODUCTION}

Picocyanobacteria (Pcy, 0.2-2 $\mu \mathrm{m}$ ) have been considered key organisms in ecological issues regarding phytoplankton diversity, competition models and niche partitioning (Stomp et al. 2004; Ahlgren, and Rocap 2006). The space-time dynamics of freshwater Pcy along environmental gradients have been extensively studied by means of microscopic and flow cytometric investigations (Callieri, and Piscia 2002; Crosbie et al. 2003a; Sarmento et al. 2008). In temperate lakes, the biomass maxima generally conform to a typical bimodal pattern, with a spring or early summer peak and a second peak in late summer or autumn (Stockner et al. 2000). This is the case in most of the subalpine deep lakes, such as Lake Maggiore (Callieri 2007), Lake Constance (Gaedke, and Weisse 1998), and Lake Stechlin (Padisák et al. 2003). Nevertheless, in Lake Maggiore during the process of re-oligotrophication (from 1992 on) the spring peak has been low or absent (Callieri 2010) as in the case of the ultraoligotrophic Lake Tahoe (Winder 2009).

The sharp fluctuations in Pcy population abundance are difficult to predict, as the pattern is caused by the interaction of various factors. Among the biotic factors, grazing (Callieri et al. 2002) and viral lysis (Personnic et al. 2009) strongly influence seasonality and prokaryote community structure. Abiotic forcing also plays a role in driving Pcy dynamics. Changing physical and chemical variables in temperate lakes seem to support the coexis- tence of multiple Pcy genotypes (Postius, and Ernst 1999), resulting in a succession of Pcy subpopulations throughout the year. This pattern has been found in Lake Constance and suggests seasonal changes in Pcy community composition (Ernst et al. 2000). More recently, biomolecular tools (e.g., fingerprinting, clone libraries, Taq nuclease assays) have permitted detailed tracking of Synechococcus in different lakes. In Lake Constance, the dynamics of single Synechococcus genotypes were followed over two years in a depth integrated sample: some strains dominated the population, while other isolates were only traced sporadically (Becker et al. 2002; 2007). In Lake Superior, two novel clusters of Pcy have been found that dominate pelagic waters (Ivanikova et al. 2007). Despite a number of studies tried to describe ideal habitat-related patterns of distribution of Synechococcus genotypes, many aspects of their possible niche differentiation along the vertical gradient remain unclear. In order to enlighten the potential structure and dynamics of persistent and differentiated subpopulations of Pcy we covered an annual cycle of distribution at two depths, which can be considered potential different niches for Pcy growth. The research took over in the oligotrophic Lake Maggiore (Northern Italy) where Pcy abundance was monitored since 1992. Moreover, the main parameters that are potential drivers for Pcy dynamics were analyzed. Pcy community structure was characterized through finger-printing approach (ARISA: Automated Ribosomal In- 
tergenic Spacer Analyse, Fisher, and Triplett 1999) that is still used for non-quantitative analysis of microbial community structure (Ramette 2009) and of their dynamics (Newton et al. 2006).

\section{MATERIALS AND METHODS}

Study site, sampling strategy and environmental parameter measurements

The research was carried out in Lake Maggiore, a large deep subalpine lake, which is now in an oligotrophic state (Salmaso et al. 2007; Bertoni et al. 2010). A total of 12 samples were collected fortnightly at the deepest point (Ghiffa: $372 \mathrm{~m}$ ) from March to September 2006 (for the dates see Tab. 1) at two fixed depths ( $3 \mathrm{~m}$ and $20 \mathrm{~m}$ ) using Niskin bottles. The samples were kept in the dark and immediately processed ( $\sim 1$ hour) after sampling. The depth of $3 \mathrm{~m}$ was selected because Photosynthetically Active Radiation (PAR) is always higher than $10 \%$ of surface PAR and also because this is the typical depth of phytoplankton peak abundance in Lake Maggiore (Callieri, and Piscia 2002). The depth of $20 \mathrm{~m}$ was chosen because it is always deeper than the depth of mixing $\left(Z_{m}\right)$ and has around $0.1 \%$ of surface PAR. Seven main parameters that affect growth and hence are potential drivers for Pcy dynamics were analyzed: temperature, mixing depth, PAR, in vivo chlorophyll, $\mathrm{pH}$, Total Phosphorus (TP) and Soluble Reactive Phosphorus (SRP). The first five environmental variables were measured using the IDRONAUT OS316 multiparameter submersible probe.

Soluble Reactive Phosphorus (SRP) was analyzed after gentle filtration through GF/C (Whatman) filters, while Total Phosphorus (TP) was analyzed on unfiltered sample. The samples were digested with potassium persulphate at $125^{\circ} \mathrm{C}$ at $1.5 \mathrm{~atm}$ for 1 hour. Phosphorus concentrations were obtained through the ascorbate-reduced molybdenum method (A.P.H.A. 1992).

\section{Picocyanobacteria enumeration}

Samples $(50 \mathrm{~mL})$ were immediately fixed using formalin ( $1 \%$ final solution) cacodylate buffered and stored in the dark at $4{ }^{\circ} \mathrm{C}$ for one day. Pcy were enumerated using an epifluorescence microscope (Zeiss Axioplan equipped with an HBO $100 \mathrm{~W}$ lamp, a Neofluar $100 \times$ objective, $1.25 \times$ additional magnification, and filter sets for blue and green light excitation, Zeiss filter set 09:BP450-490, FT510, LP520, Zeiss filter set 14: LP510-KP560, FT580, LP590) after filtration through $0.2 \mu \mathrm{m}$ Nuclepore polycarbonate filters. Images for morphometric analysis and cell biovolume calculations were elaborated using an image analysis system (Image-Pro Plus software).

Community composition analysis (DNA extraction, Polymerase Chain Reaction and ARISA)

About $300 \mathrm{~mL}$ of lake water from each sample was concentrated on a $0.2 \mu \mathrm{m}$ Supor $^{\circledR}$ (Gelman Laboratory) and the filters kept at $20^{\circ} \mathrm{C}$ in $2 \mathrm{~mL}$ of lysis buffer $(50 \mathrm{mM}$ Tris, $40 \mathrm{mM}$ EDTA, $400 \mathrm{mM} \mathrm{NaCl}, 0.75 \mathrm{M}$ Sucrose) for no longer than 2 months. Nucleic acid extraction was performed directly from the filters using the UltraClean Bacterial Soil DNA Kit (Mobio Laboratories Inc., California) following the yield maximization protocol suggested by the manufacturer. DNA extractions were checked on $0.8 \%$ agarose-TBE (Tris-Borate-EDTA, Promega). Each extract was also quantified using a QuBit Fluorometer (Invitrogen) and stored at $20^{\circ} \mathrm{C}$ until further analysis.

PCR reactions were performed in a seminested procedure as described in Caravati et al. (2010). Briefly, $2 \mathrm{ng}$ of total extracted DNA was used as a template for the first PCR using 16S-359F (5'-GGGGAATYTTC CGCAATGGG-3') and 23S-125R (5'-GGGTTBCCC CATTCRG-3'). About $2 \mu \mathrm{L}$ of each amplified sample were used as a template for the second PCR, performed with 16S-CSIF (5'-GYCACGCCCGAAGTCRTTAC-3', Janse et al. 2003) and 23S-125R (in this case TET labelled

Tab. 1. Environmental parameters measured during the campaign. Zeup: depth of the euphotic layer, Zm/Zeup: ratio of depth of mixing layer to euphotic layer, $\mathrm{pH}, \mathrm{T}$ : temperature, Chl: in situ chlorophyll, TP: total phosphorus, SRP: soluble reactive phosphorus.

\begin{tabular}{|c|c|c|c|c|c|c|c|}
\hline Sampling & $Z_{\text {eup }}(m)$ & $\mathrm{Z}_{\mathrm{m}} / \mathrm{Z}_{\text {eup }}$ & $\mathrm{pH}$ & $\mathrm{T}\left({ }^{\circ} \mathrm{C}\right)$ & $\operatorname{Chl}\left(\mu \mathrm{g} \mathrm{L}^{-1}\right)$ & $\mathrm{TP}\left(\mu \mathrm{g} \mathrm{L}^{-1}\right)$ & $\operatorname{SRP}\left(\mu \mathrm{g} \mathrm{L}^{-1}\right)$ \\
\hline & & & $3 m-20 m$ & $3 m-20 m$ & $3 m-20 m$ & $3 m-20 m$ & $3 m-20 m$ \\
\hline 22 March & 26.0 & 3.85 & $7.5-7.3$ & $6.70-6.22$ & $1.16-0.47$ & $11.5-10.5$ & $2.2-6.7$ \\
\hline 06 April & 12.5 & 4.00 & 7.8-7.6 & $8.20-7.32$ & $1.12-2.23$ & 7.4-6.3 & $0.3-02$ \\
\hline 20 April & 12.5 & 2.80 & $8.5-7.7$ & $9.80-7.19$ & $1.68-3.33$ & $14.0-9.2$ & $1.3-1.4$ \\
\hline 10 May & 8.50 & 0.88 & $8.9-7.6$ & $13.46-8.72$ & $3.77-2.15$ & $13.4-8.6$ & $0.2-0.8$ \\
\hline 24 May & 12.5 & 0.52 & $8.4-7.2$ & $16.70-8.49$ & $1.55-0.65$ & $10.8-6.2$ & $1.3-1.3$ \\
\hline 07 June & 12.0 & 0.71 & $8.4-7.7$ & $14.96-8.86$ & $0.97-1.14$ & $11.1-7.8$ & $1.3-1.1$ \\
\hline 21 June & 16.0 & 0.22 & - & $22.08-9.76$ & $0.79-1.26$ & - & - \\
\hline 20 July & 12.5 & 1.24 & $8.9-7.5$ & $25.28-10.87$ & $1.17-1.63$ & $10.9-9.7$ & $1.1-1.2$ \\
\hline 09 August & 12.5 & 0.92 & $8.9-7.4$ & $22.87-9.87$ & $0.68-0.55$ & $9.4-6.8$ & $0.7-1.6$ \\
\hline 23 August & 13.0 & 0.77 & $8.8-7.4$ & $21.60-10.86$ & $0.55-0.31$ & $7.1-7.9$ & $0.8-1.8$ \\
\hline 05 September & 10.0 & 1.50 & $8.9-8.0$ & $21.43-12.24$ & $0.94-0.44$ & $3.0-7.0$ & - \\
\hline 19 September & 16.0 & 0.78 & $8.6-7.4$ & 20.19-12.78 & $0.65-0.34$ & $10.1-8.5$ & $0.9-1.8$ \\
\hline
\end{tabular}


in $\left.5^{\prime}\right)$. The PCRs were executed in a volume of $50 \mu \mathrm{L}$ containing forward and reverse primers (each at $0.3 \mu \mathrm{M}$ ) and $20 \mu \mathrm{L}$ of PCR Master Mix (Promega). Thirty PCR cycles were used for the consecutive amplifications step, consisting of $94^{\circ} \mathrm{C}$ for $1 \mathrm{~min}, 55^{\circ} \mathrm{C}$ for $1 \mathrm{~min}$, and $72^{\circ} \mathrm{C}$ for 2 min, preceded by $3 \mathrm{~min}$ of denaturation at $94^{\circ} \mathrm{C}$ and followed by a final extension of $10 \mathrm{~min}$ at $72^{\circ} \mathrm{C}$. The final amplifications were purified using a PCR Purification Kit (Qiagen) and quantified using a QuBit Fluorometer (Invitrogen), and stored at $20^{\circ} \mathrm{C}$.

Pcy community structure was analyzed using the ARISA fingerprinting technique, which amplifies the Internal Transcribed Spacer (ITS) region in the rRNA operon plus a small part of the 16S rRNA and 23S rRNA genes (Fisher, and Triplett 1999). The purified TET-labelled PCR products were denatured ( $3 \mu \mathrm{L}$ of PCR product, $2.5 \mu \mathrm{L}$ of deionised formamide and $0.5 \mu \mathrm{L}$ of internal size standard; ROX 2500, Applied Biosystems) at $94^{\circ} \mathrm{C}$ for $2 \mathrm{~min}$, then chilled on ice and carried for the analysis. Electrophoresis was carried out at $2800 \mathrm{~V}$ for $7 \mathrm{~h}$ in a denaturing $5 \%$ acrylamide gel with an ABI Prism 377 automated sequencer. The ARISA Fragments Length was determined by comparison with the ROX 2500 internal size standard (Applied Biosystems) by using the Local Southern size-calling method in GeneScan 3.7 (Applied Biosystems). Each ARISA peak corresponds to one genetic variant and was used as proxy for a single taxon or OTU. The profiles of different runs were aligned using the procedure described in Caravati et al. (2010). We binned the peaks in different fixed windows depending on fragment length $(300 / 700-$ $3 \mathrm{bp}, 700 / 1000-5 \mathrm{bp},>1000-10 \mathrm{bp}$ ). The peak heights of all ARISA profiles collected from the samples were then standardized (Dunbar et al. 2001). Peaks smaller than 350 bp and longer than $1300 \mathrm{bp}$ in size were not considered because the amplified fragments are composed of the ITS region plus 300-350 bp belonging to the adjacent genes. All the "shoulder peaks" were eliminated. The detection threshold $(0.24 \%$ of total fluorescence) was calculated according to Luna and coworkers (2006).

\section{Calculations, data treatment and statistical analysis}

The depth of mixing layer $\left(\mathrm{Z}_{\mathrm{m}}\right)$ can be defined as the depth at which the temperature gradient is greatest and was calculated by analyzing the vertical thermal profile. Finding two different gradients, we selected the one with the highest gradient (Hocking, and Straškraba 1999). The maximum depth of the light zone is designated as the euphotic depth $\left(Z_{\text {eup }}\right)$, and is estimated as the depth where light energy is reduced to $1 \%$ of the intensity immediately below the surface. The ratio $Z_{\mathrm{m}} / Z_{\text {eup }}$ is an indirect estimate of light availability in the mixing layer.

Richness, Shannon-Weaver diversity index and evenness were calculated according to Pielou (Pielou 1984) based on ARISA OTU relative fluorescence. The similar- ity index (Bray-Curtis) within pairs of samples was also calculated using the PopTools free software and clusters were built using the Unweighted Paired Group Mean Average (UPGMA).

Statistical differences were tested via a paired $t$-test and Two Way ANOVA. Normality and homoscedasticity were checked and transformations were applied when necessary to fulfil these conditions. All statistics were performed using SigmaStat 3.1.

The relationships among species (OTUs) and environmental variables were explored via Redundancy Data Analysis (RDA, CANOCO 4.5). The environmental variables used in the multivariate data analysis were temperature, mixing depth, PAR, in vivo chlorophyll, TP, SRP and $\mathrm{pH}$. All the variables were included in the model, following Manual Forward Selection (ter Braak, and Šmilauer 2002). In this process, each variable is included in the model manually in consecutive steps. Every new variable was tested and permuted (Montecarlo Test, 1000 permutations) and only the environmental variables that had $p<0.05$ were definitely included in the RDA. Each individual OTU was square root transformed to avoid causing imbalances in the analyses due to the most abundant OTUs.

\section{RESULTS}

Physico-chemical characteristics

Lake Maggiore is a temperate holo-oligomictic lake. The isopleth map (not shown) shows the distribution of the thermocline from May to early October. Thermal stability of water masses (indicated by $\mathrm{Z}_{\mathrm{m}}$ ) extends from 3.5 $\mathrm{m}$ (June 21) to over $30 \mathrm{~m}$ (early spring) (Fig. 1). The depth of the euphotic zone $Z_{\text {eup }}(1 \%$ of surface PAR) reached its

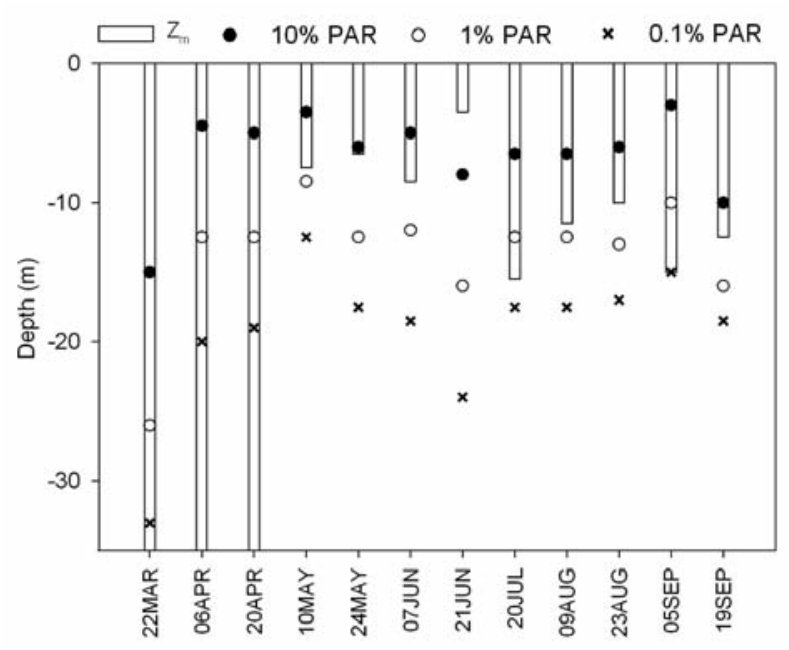

Fig. 1. Dynamics of mixing layer depth $\left(\mathrm{Z}_{\mathrm{m}}=\right.$ hystograms $)$, at $10 \%, 1 \%$ and $0.1 \%$ of surface PAR (respectively closed circles, open circles and crosses). The horizontal lines mark sampling depths. 
maximum in March (26 $\mathrm{m})$ and its minimum in May (8.5 m) (Tab. 1).

The depth of $10 \%$ of PAR was deeper than $3 \mathrm{~m}$ and that of $0.1 \%$ PAR was often around $20 \mathrm{~m}$ (Fig. 1). During stratification, the two selected depths were separated by the thermocline, so that the depth of $3 \mathrm{~m}$ was always in the mixing zone and had more than $10 \%$ of surface PAR and the depth of $20 \mathrm{~m}$ was in the hypolimnion with limited light. The two depths therefore represent different light niches for Pcy.

The ratio $Z_{m} / Z_{\text {eup }}$ progressively decreases from March to June and remains around 1 in summer and autumn (Tab. 1). This ratio is an estimate of light availability in the mixing layer therefore the highest values in March and April indicate a possible light limitation at the beginning of stratification. The lowest value was reached on June 21 with clear water and shallow termocline.

TP reached its peak on April 20 at $3 \mathrm{~m}(14 \mu \mathrm{g} \mathrm{L}-1)$ and its minimum on September 5 at $3 \mathrm{~m}\left(3 \mu \mathrm{g} \mathrm{L}^{-1}\right)$ (Tab. 1). SRP was $<2 \mu \mathrm{g} \mathrm{L}^{-1}$ at both depths with the exception of the $6.7 \mu \mathrm{g} \mathrm{L}^{-1}$ reached at $20 \mathrm{~m}$ at the beginning of stratification. There was no significant difference (paired $t$-test) between TP and SRP at $3 \mathrm{~m}$ and at $20 \mathrm{~m}$. On the other hand there was a significant inverse correlation between $\mathrm{TP}$ and Pcy numbers at $3 \mathrm{~m}$ ( $\mathrm{r}$ Spearman $=0.655, \mathrm{p}<0.05)$. in vivo chlorophyll a (Tab. 1) showed a spring peak, in April at $20 \mathrm{~m}$ and in May at $3 \mathrm{~m}$.

In summer, chlorophyll a was around $1 \mu \mathrm{g} \mathrm{L}^{-1}$ but frequently fell below this value at both depths, indicating the actual oligotrophic state of the lake. The $\mathrm{pH}$ showed significant difference between the two depths (Mann Whitney Rank Sum Test, $\mathrm{p}<0.001$ ), with higher values at $3 \mathrm{~m}$, particularly in summer.

Picocyanobacterial community structure (dynamics, morphology and diversity)

In September, Pcy reached $350 \times 10^{3}$ cells $\mathrm{mL}^{-1}$ at $3 \mathrm{~m}$ (Fig. 2). At $20 \mathrm{~m}$, Pcy abundance was never higher than $50 \times 10^{3}$ cells $\mathrm{mL}^{-1}$. On average over the period, Pcy cell biovolume was $0.63 \mu \mathrm{m}^{3}$ cell $^{-1}$ and showed its high-est value in March $\left(1.44 \mu \mathrm{m}^{3}\right.$ cell $\left.^{-1}\right)$. The lowest biovolumes were recorded in May $\left(0.12 \mu \mathrm{m}^{3}\right.$ cell $\left.^{-1}\right)$.

At $20 \mathrm{~m}$, diversity (Shannon Index) was higher in summer and lower in early spring. Conversely, the highest richness and diversity at $3 \mathrm{~m}$ was found from March to July. There was a significant difference $(t$-test, $p=0.04)$ between the Shannon Index at $3 \mathrm{~m}$ and at $20 \mathrm{~m}$, with the highest values found at $20 \mathrm{~m}$. The diversity was only inversely correlated with the number of Pcy at $3 \mathrm{~m}$ ( $r$ Spear$\operatorname{man}=0.6, p=0.046$ ).

The space-time dynamics (Fig. 3) of the standardized relative fluorescence signal of each individual OTU explored by ITS analysis showed a very complex distribution with a succession of different OTUs. OTU 1139 ,

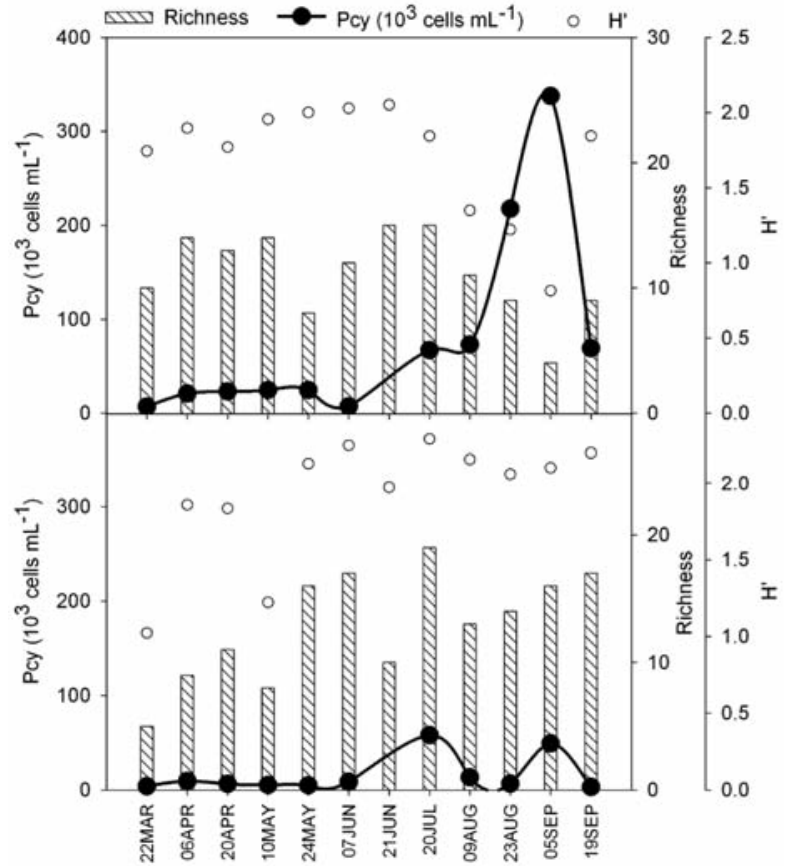

Fig. 2. Dynamics of Pcy abundances (line with closed circles), OTU richness (hystogram) and Shannon diversity index (H'= open circles) at $3 \mathrm{~m}$ (upper panel) and $20 \mathrm{~m}$ (lower panel), in Lake Maggiore.

typical of spring months at both depths, was replaced by OTU 1073 in summer and contributed up to $70 \%$ of the total fluorescence signal at $3 \mathrm{~m}$ in September. OTU 588 was characteristic of deeper samples in summer and OTU 526 constituted an important fraction (up to 33\%) in summer samples at both depths.

The similarity between pairs of samples (Fig. 4) calculated using the Bray-Curtis index revealed (distance linkage $=0.35$ ) two different subclusters which characterize spring and late summer Pcy communities. Moreover, in the summer two distinct clusters of Pcy ( 0.28 distance) were formed at $3 \mathrm{~m}$ and at $20 \mathrm{~m}$. This separation between the two depths was not visible in spring samples.

RDA multivariate analysis (Fig. 5) was performed using only three environmental variables which passed the Monte Carlo test $(p<0.05)$ : temperature ( $\mathrm{T}, p<0.001)$, $\mathrm{pH}(\mathrm{pH}, p=0.01)$ and mixing depth $\left(\mathrm{Z}_{\mathrm{m}}, p=0.037\right)$. The eigenvalues of the first two ordination axes were respectively 0.653 and 0.214 . We found correlations between axis 1 and temperature, $\mathrm{pH}$ and $\mathrm{Z}_{\mathrm{m}}$ of respectively 0.85 , $0.64,0.61$. OTU distributions were controlled by variations in physico-chemical parameters. In particular, the co-occurrence of OTUs 1073, 539 and 987 was positively correlated with temperature, while the occurrence of OTUs 588, 754 and 732 was inversely correlated with temperature. Some OTUs $(685,376,480$ and others) were not correlated with any of the environmental variables. In 


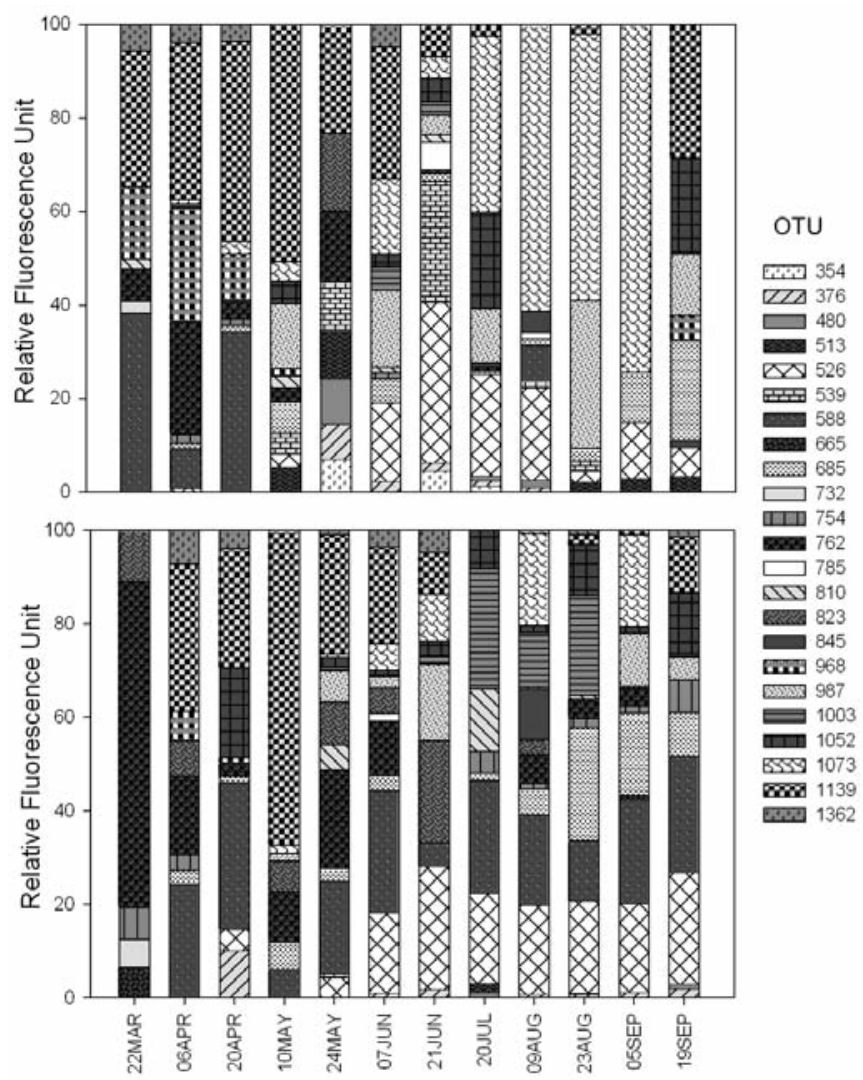

Fig. 3. Space-time dynamics (upper panel: $3 \mathrm{~m}$ and lower panel: $20 \mathrm{~m}$ ) of the percentage of operational taxonomic units (OTU, >5\%) obtained using ARISA.

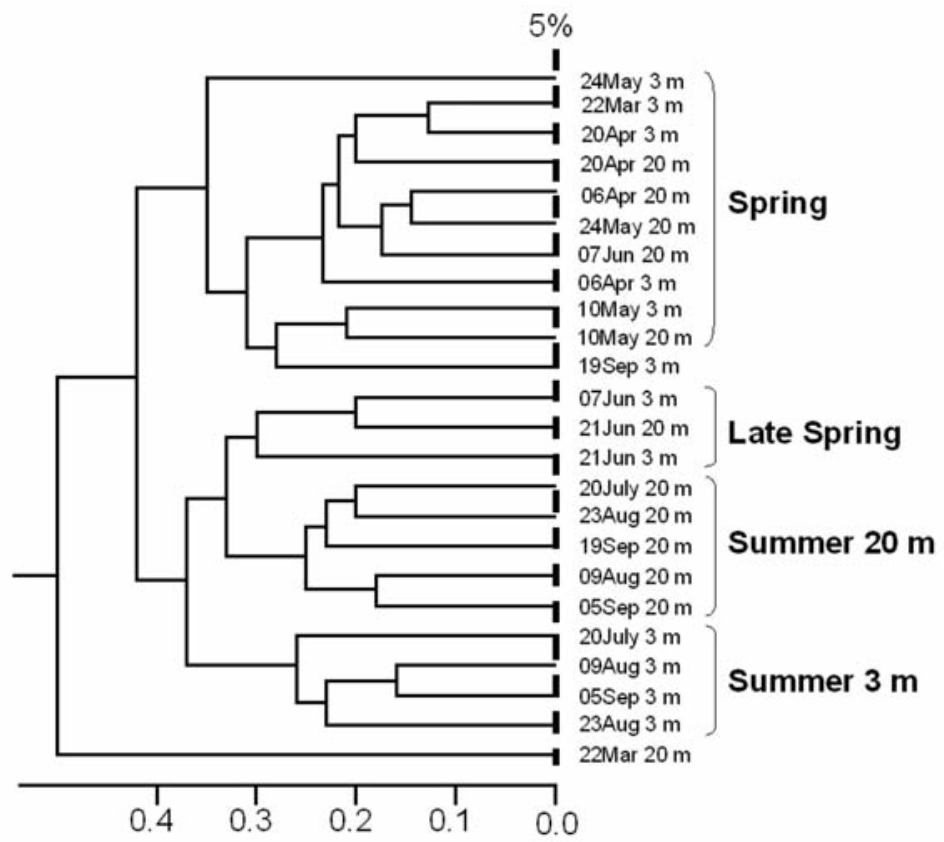

Fig. 4. UPGMA clustering of Bray-Curtis similarity indexes for the picocyanobacterial community of Lake Maggiore, obtained through ARISA. 


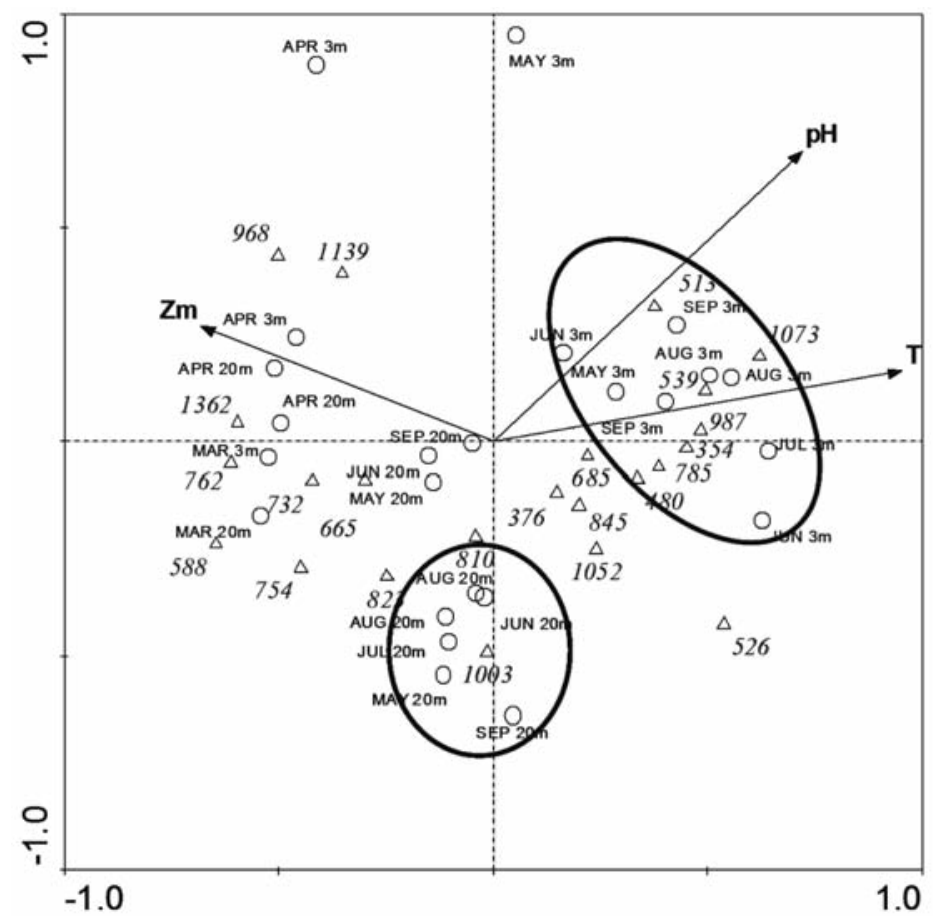

Fig. 5. Triplots (RDA) along the two main axes of variation for the dominant OTU (triangles), significant environmental variables (p $<0.05$ ) and sampling dates (circles). The two clusters of $3 \mathrm{~m}$ and $20 \mathrm{~m}$ are marked with ellipses. $\mathrm{T}=$ temperature, $\mathrm{Zm}=$ mixing depth.

this ordination plot, the sampling data in summer were distributed differently for the two depths: $3 \mathrm{~m}$ data were controlled by the first axis, while $20 \mathrm{~m}$ data were controlled by the second axis.

\section{DISCUSSION}

Picocyanobacteria seasonal succession

Numerous studies of Pcy dynamics and activity in Lake Maggiore have demonstrated the importance of this autotrophic size-fraction as percent biomass contribution to total autotrophic biomass (Callieri 2007). As for most lakes in temperate regions, maximum Pcy abundance generally conforms to a typical bimodal pattern, with a spring or early summer peak and a second peak in summer or autumn (Stockner et al. 2000).

However, if we look at the long-term series of Pcy abundance, not only in Lake Maggiore (Callieri, and Piscia 2002) but also in Lake Constance (Gaedke, and Weisse 1998) and Lake Stechlin (Padisák et al. 2003), not all years are clearly bimodal. The interannual variability of Pcy dynamics, with the absence of a spring peak, is likely due to weak spring stratification and relatively deep vertical mixing (Weisse 1993). Our study in Lake Maggiore showed the absence of a spring peak in Pcy and of a DCM (Deep Chlorophyll Maxima) at $20 \mathrm{~m}$ during 2006. Nevertheless, the ITS-1 fragment length clearly outlined a succession of OTUs from spring to summer at both $3 \mathrm{~m}$ and $20 \mathrm{~m}$. This fact demonstrates that, even if there was no bimodal pattern of cell numbers, bimodal community composition succession was evident. The information given by ITS fragment length varies among taxa so that Pcy microdiversity can be studied with ARISA to identify different ecotypes, even if the data obtained are not quantitative (Brown et al. 2005). A rapid succession of individual Pcy clades, illustrating the patchy structure of the Pcy community, was described over a quite small spatial/temporal scale for lakes in the English Lake District using quantitative PCR (Sánchez-Baracaldo et al. 2008). Although we did not perform quantitative PCR, we still obtained a fairly detailed picture of OTU succession in Lake Maggiore. Similar results have been obtained for other microbial communities (Hewson, and Fuhrman 2004; Danovaro et al. 2006) and, in the case of Pcy, may result in the succession of Synechococcus ecotypes already hypothe-sized by Postius, and Ernst (1999). Such a variety of genotypic diversity among Pcy communities also reflects the different morphotype composition observed in spring and summer assemblages, with a dominant presence of single cells in spring and an increase in microcolonies in late summer (Callieri 2010). Previous studies using different fingerprinting techniques on $16 \mathrm{~S}$ DNA provided evidence of different community composition in spring and late summer in Lake Maggiore (Callieri et al. 2007). Sequencing of the most prominent bands showed one spring OTU affiliated with Synechococcus subalpine cluster I, with $100 \%$ similarity to LM94, MW76B2 and MW15\#2 (sensu Crosbie et al. 2003b), 
which was not present in late summer. Another OTU, present both in spring and in late summer, showed 100\% similarity to MH301, a strain similar to subalpine cluster II (Callieri et al. 2007). In the present study, we used the least-conserved ITS region and extended the measurements to a seasonal scale, thus strengthening previous results. We also observed the constant presence of two OTUs throughout the year. This finding was in accordance with the more accurate quantification of the genotype Synechococcus BO 8807 isolated in the pelagic zone of Lake Constance (Becker et al. 2007).

Niche partitioning along the vertical gradient

Light is considered a major factor in niche differentiation in various aquatic ecosystems. While the adaptation of Pcy ecotypes to high and low light has been assessed in the oceans (Johnson et al. 2006; Scanlan et al. 2002), in freshwaters niche adaptation mechanisms of Pcy (mainly Synechococcus and Cyanobium) with respect to light are not so clear (Kettler et al. 2007). Temperature, as well as light, is another important factor in niche differentiation. In marine habitats, temperatures under the threshold of $14^{\circ} \mathrm{C}$ have been identified as being directly related to mean annual Pcy abundance (Li 1998). In freshwaters maximal concentrations of Pcy were observed at an optimum temperature of between $18^{\circ} \mathrm{C}$ and $20^{\circ} \mathrm{C}$ and at the depth of the thermocline (Callieri, and Piscia 2002). Thermal conditions are important not only for the ambient water temperature per se, but for the maintenance of a density gradient resisting settlement (Callieri 2007).

In this study, we selected two niches: one at a depth of $3 \mathrm{~m}$ that receives from 100 to $300 \mu \mathrm{mol}$ photons $\mathrm{m}^{-2}$ $\mathrm{s}^{-1}$ and has a mean temperature of $17^{\circ} \mathrm{C}$ and another at $20 \mathrm{~m}$ with 1 to $10 \mu \mathrm{mol}$ photons $\mathrm{m}^{-2} \mathrm{~s}^{-1}$ and a temperature of $9^{\circ} \mathrm{C}$ (Caravati 2003). The range of photon flux and the different temperatures can be optimal for distinguishing differently adapted Pcy, particularly in summer when stratification occurs and separates the two environmental niches.

The data showed vertical partitioning of Pcy OTUs down the water column, more evident in summer (Fig. 4), when two Pcy clusters, composed of different OTUs, clearly separate at $3 \mathrm{~m}$ and $20 \mathrm{~m}$. This indicates differences in community composition between the two depths. Our results support the coexistence of ecotypes in the vertical gradient, rapidly acclimating and performing differently in the various microhabitats.

In a previous study, we observed that Pcy has different photosynthetic characteristics at different depths in Lake Maggiore, but were unable to show differences in OTU composition in the vertical profile of the water column using DGGE and the 16S DNA gene (Callieri et al. 2007). In the present study, we documented the presence or absence of OTUs at two different depths over an entire sea- sonal cycle. In this way, we clarified that in absence of any stable stratification, the community composition in terms of OTUs were similar at $3 \mathrm{~m}$ and $20 \mathrm{~m}$ up to the end of April. The appearance of stratification in May creates different niches colonized by specific OTUs. This is the case for OTU 588, which remains in the $20 \mathrm{~m}$ layer but almost disappears in the upper layer. In marine systems, distinct Pcy lineages have also been shown to occur in waters having different environmental characteristics; this feature is evident over large spatial scales (Fuller et al. 2006; Zwirglmaier et al. 2007, 2008). The depthrelated distribution pattern of Pcy OTUs we observed is a first clear indication of niche partitioning in a large deep oligotrophic lake where Synechococcus is found at different depths (Callieri et al. 2007).

\section{Effects of environmental variables on Pcy dynamics}

Of the 7 parameters examined, only three were found to be significant in RDA analysis: temperature $(p<0.001)$, $\mathrm{Z}_{\mathrm{m}}(p=0.037)$ and $\mathrm{pH}(p<0.01)$. The analysis was highly significant: $86.7 \%$ of the variance was explained by two axes. $\mathrm{pH}$ resulted to be significant in explaining OTU dynamics, but the effect of this parameter could be indirect. Temperate lakes typically show a summer increase in $\mathrm{pH}$ parallel to the increase in phytoplanktonic production, which decreases free $\mathrm{CO}_{2}$. This fact could also induce changes in the Pcy community structure. Temperature is highly positively correlated with axis $1(0.85)$. Lake thermal structure, defined by temperature $(\mathrm{T})$ and depth of mixing layer $\left(Z_{\mathrm{m}}\right)$, influences Pcy abundance and dynamics through the effect of temperature per se and mass water movements in response to density gradients. Higher temperatures generally enhance the growth rate of phytoplankton and increase the reaction rate of RuBisCo (Beardall, and Raven 2004). However, it is difficult to separate the influence of temperature on the abundance of Pcy in lakes from the influence of other seasonal dependent variables. Weisse (1993) suggested that temperature is an important factor in triggering the onset of Pcy growth in marine and freshwater environments, but not in regulating their population dynamics. No data exist on the effects of temperature on Pcy diversity in natural systems. Our results indicate that some OTUs are typical of periods with higher temperature (summer) and others are observed when lake water is colder (Fig. 5). In Lake Maggiore, the maximum Pcy concentration occurs near the thermocline and at temperatures between $18^{\circ} \mathrm{C}$ and $20^{\circ} \mathrm{C}$ (Callieri, and Piscia 2002). However, the significant relation we found between temperatures and Pcy OTUs should be interpreted more as side-effect of seasonal changes.

In other freshwater and marine systems, the temperature gradient and stability of the water column appears to affect Pcy abundance and dynamics (Camacho et al. 2003; 
Fuller et al. 2005). Here we would like to add a piece of information we found concerning the relationship between $Z_{\mathrm{m}}$ and Pcy diversity. In May and June, we observed the lowest values of $Z_{\mathrm{m}}$ in conjunction with the highest OTU diversity at $3 \mathrm{~m}$. In July, the increase in $Z_{\mathrm{m}}$ corresponded to high richness at both depths. The ratio $\mathrm{Z}_{\mathrm{m}} / \mathrm{Z}_{\text {eup }}$ (significantly correlated to $\mathrm{Z}_{\mathrm{m}}: r=0.89, p=0.0001$ ) indicates the proportion between the light and dark zones in the mixing layer, related to algal light-adaptive response (Reynolds 1984). A low value of this ratio indicates that the mixing zone is well illuminated, while a high value shows that light is limited in the mixing zone. It is known that Pcy outcompete other autotrophs in low light conditions (Callieri 2007) and this could be the reason for the increase in diversity at $20 \mathrm{~m}$. In other words, the high $Z_{m} / Z_{\text {eup }}$ ratio and the higher diversity observed in July suggest that Pcy communities can stimulate their adaptive traits in conditions of light limitation and consequently increase their diversity. Although light was not a significant factor in the RDA analysis, we think its importance is expressed through the $Z_{m} / Z_{\text {eup }}$ ratio. In this sense, light is an important factor but only if considered as an intrinsic property of the water mass, with its own thermal structure.

In conclusion the Pcy community structure in Lake Maggiore showed a remarkable succession of the OTUs defined by the least conserved ITS-1 fragment length. The thermal structure, defined by temperature $(\mathrm{T})$ and depth of mixing layer $\left(\mathrm{Z}_{\mathrm{m}}\right)$, influences OTU dynamics. There are "summer" OTUs typical of warmer waters in superficial layers and "early spring" OTUs typical of colder waters. In summer, microdiversity was clearly visible in the vertical gradient, with an increase of diversity at $20 \mathrm{~m}$.

\section{REFERENCES}

A.P.H.A. 1992. Standard methods for the examination of water and wastewater. Am. Publ. Health Ass., Washington.

Ahlgren NA, and Rocap G. 2006. Culture isolation and cultureindependent clone libraries reveal new marine Synechococcus ecotypes with distinctive light and $\mathrm{N}$ physiologies. Appl. Environ. Microbiol. 72: 7193-7204.

Beardall J, and Raven JA. 2004. Potential effects of global change on microalgal photosynthesis, growth and ecology. Phycologia 43: 26-40.

Becker S, Fahrbach M, Boger P, and Ernst A. 2002. Quantitative tracing, by Taq nuclease assays, of a Synechococcus ecotype in a highly diversified natural population. Appl. Environ. Microbiol. 68: 4486-4494.

Becker S, Richl P, and Ernst A. 2007. Seasonal and habitat-related distribution pattern of Synechococcus genotypes in Lake Constance. FEMS Microbiol. Ecol. 62: 64-77.

Bertoni R, Callieri C, Corno G, Rasconi S, Caravati E, and Contesini M. 2010. Long-term trends of epilimnetic and hypolimnetic bacteria and organic carbon in a deep holo-oligomictic lake. Hydrobiologia 644: 279-287.

Brown MV, Schwalbach MS, Hewson I, and Fuhrman JA. 2005.
Coupling 16S-ITS rDNA clone libraries and automated ribosomal intergenic spacer analysis to show marine microbial diversity: development and application to a time series. Environ. Microbiol. 7: 1466-1479.

Callieri C, and Piscia R. 2002. Photosynthetic efficiency and seasonality of autotrophic picoplankton in Lago Maggiore after its recovery. Freshwater Biol. 47: 941-956.

Callieri C, Karjalainen SM, and Passoni S. 2002. Grazing by ciliates and heterotrophic nanoflagellates on picocyano-bacteria in Lago Maggiore, Italy. J. Plankton Res. 24: 785-796.

Callieri C. 2007. Picophytoplankton in freshwater ecosystems: the importance of small-sized phototrophs. Freshwater Rev., 1: 1-28, DOI: 10.1608/FRJ/1.1.1

Callieri C. 2010. Single cells and microcolonies of freshwater picocyanobacteria: a common ecology. J. Limnol. 69: 257-277.

Callieri C, Corno G, Caravati E, Galafassi S, Bottinelli M, and Bertoni R. 2007. Photosynthetic characteristics and diversity of freshwater Synechococcus at two depths during different mixing conditions in a deep oligotrophic lake. J. Limnol. 66: 81-89.

Camacho A, Miracle MR, and Vicente E, 2003. Which factors determine the abundance and distribution of picocyanobacteria in inland waters? A comparison among different types of lakes and ponds. Arch. Hydrobiol. 157: 321-338.

Caravati E. 2003. Le comunità autotrofe pelagiche del Lago Maggiore: dinamica, produzione ed interazioni. PHD Thesis University of Parma: $171 \mathrm{pp}$. (available in pdf format at URL http://dspace-unipr.cilea.it/bitstream/1889/950/1/Phd Thesis Emanuele Caravati.pdf).

Caravati E, Callieri C, Modenutti B, Corno G, Balseiro E, Bertoni R, and Michaud L. 2010. Picocyanobacterial assemblages in ultraoligotrophic Andean lakes reveal high regional microdiversity. J. Plankton Res. 32: 357-366.

Crosbie ND, Teubner K, and Weisse T. 2003a. Flow-cytometric mapping provides novel insights into the seasonal and vertical distributions of freshwater autotrophic picoplankton. Aquat. Microb. Ecol. 33: 53-66.

Crosbie ND, Pöckl M, and Weisse T. 2003b. Dispersal and phylogenetic diversity of nonmarine picocyanobacteria, inferred from 16S rRNA gene and cpcBA-intergenic spacer sequence analyses. Appl. Environ. Microbiol. 69: 5716-5721.

Danovaro R, Luna GM, Dell'Anno A, and Pietrangeli B. 2006. Comparison of two fingerprinting techniques, terminal restriction fragment length polymorphism and automated ribosomal intergenic spacer analysis, for determination of bacterial diversity in aquatic environments. Appl. Environ. Microbiol. 72: 5982-5989.

Dunbar J, Ticknor LO, and Kuske CR. 2001. Phylogenetic specificity and reproducibility and new method for analysis of terminal restriction fragment profiles of 16S rRNA genes from bacterial communities. Appl. Environ. Microbiol. 67: 190-197.

Ernst A, Becker S, Hennes K, and Postius C. 2000. Is there a succession in the autotrophic picoplankton of temperate zone lakes? In: Bell, C.R., M. Brylinski, P. Johnson-Green (Eds), Microbial Biosystems: New Frontiers. Proceedings of the 8th International Symposium on Microbial Ecology, Halifax, Canada: Atlantic Canada Society for Microbial Ecology: 623-629.

Fisher MM, and Triplett EW. 1999. Automated approach for ri- 
bosomal intergenic spacer analysis of microbial diversity and its application to freshwater bacterial community. Appl. Environ. Microbiol. 65: 4630-4636.

Fuller NJ, Tarran GA, Yallop M, Orcutt KM, and Scanlan DJ. 2006. Molecular analysys of picocyanobacterial community structure along an Arabian sea transect reveals distinct spatial separation of lineages. Limnol. Oceanogr. 51: 25152526.

Fuller NJ, West NJ, Marie D, Yallop M, Rivlin T, Post AF, and Scanlan D. 2005. Dynamics of community structure and phosphorus status of picocyanobacterial populations in the Gulf of Aqaba, Red Sea. Limnol. Oceanogr. 50: 363-375.

Gaedke U, and Weisse T. 1998. Seasonal and interannual variability of picocyanobacteria in Lake Constance. Arch. Hydrobiol., Special Issue, Advanc. Limnol. 53: 143-158.

Hewson I, and Fuhrman JA, 2004. Richness and diversity of bacterioplankton species along an estuarine gradient in Moreton Bay, Australia. Appl. Environ. Microbiol. 70: 34253433.

Hocking GC, and Straškraba M. 1999. The effect of light extinction on thermal stratification in reservoirs and lakes. Internat. Rev. Hydrobiol. 84: 535-556.

Ivanikova NV, Popels LC, McKay RML, and Bullerjahn GS. 2007. Lake Superior supports novel clusters of cyanobacterial picoplankton. Appl. Environ. Microbiol. 73: 4055-4065.

Janse I, Meima M, Kardinaal WEA, and Zwart G. 2003. Highresolution differentiation of cyanobacteria by using rRNAinternal transcribed spacer denaturing gradient gel electrophoresis. Appl. Environ. Microbiol. 69: 6634-6643.

Johnson ZI, Zinser ER, Coe A, McNulty NP, Woodward EM, and Chisholm SW. 2006. Niche partitioning among Prochlorococcus ecotypes along ocean-scale environmental gradients. Science 311: 1737-1740.

Kettler G, Martiny AC, Huang K, Zucker J, Coleman ML, Rodrigue S, Chen F, Lapidus A, Ferriera S, Johnson J, Steglich C, Church G, Richardson P, and Chisholm SW. 2007. Patterns and implications of gene gain and loss in the evolution of Prochlorococcus. PLoS Genet., 3: e231.

Li WKW. 1998. Annual average abundance of heterotrophic bacteria and Synechococcus in surface ocean waters. Limnol. Oceanogr. 43: 1743-1753.

Luna GM, Dell'Anno A, and Danovaro R. 2006. DNA extraction procedure: a critical issue for bacterial diversity assessment in marine sediments. Environ. Microbiol., 8: 308-320.

Newton RJ, Kent AD, Triplett EW, and McMahon KD. 2006. Microbial community dynamics in a humic lake: differential persistence of common freshwater phylotypes. Environ. Microbiol. 8: 956-970.

Padisák J, Scheffler W, Kasprzak P, Koschel R, and Krienitz L, 2003. Interannual changes (1994-2000) of phytoplankton of Lake Stechlin. Arch. Hydrobiol. Special Issues, Advanc. Limnol. 58: 101-133.

Personnic S, Domaizon I, Dorigo U, Berdjeb L, and Jacquet S. 2009. Seasonal and spatial variability of virio-, bacterio-, and picophytoplanktonic abundances in three peri-alpine lakes. Hydrobiologia 627: 99-116.
Pielou EC. 1984. The interpretation of ecological data. A primer on classification and ordination. John Wiley e Sons.

Postius C, and Ernst A. 1999. Mechanisms of dominance: coexistence of picocyanobacterial genotypes in a freshwater ecosystem. Arch. Microbiol. 172: 69-75.

Ramette A. 2009. Quantitative community fingerprinting methods for estimating the abundance of operational taxonomic units in natural microbial communities. Appl. Environ. Microbiol. 75: 2495-2505.

Reynolds CS. 2006. The ecology of phytoplankton. Cambridge University Press: 535 pp.

Salmaso N, Morabito G, Garibaldi L, and Mosello R. 2007. Trophic development of the deep lakes south of the Alps: a comparative analysis. Arch. Hydrobiol. 170: 177-196.

Sánchez-Baracaldo P, Handley BA, and Hayes PK. 2008. Picocyanobacterial community structure of freshwater lakes and the Baltic Sea revealed by phylogenetic analyses and cladespecific quantitative PCR. Microbiology+ 154: 3347-3357.

Sarmento H, Unrein F, Isubmisho M, Stenuite S, Gasol J, and Descy JP. 2008. Abundance and distribution of picoplankton in tropical oligotrophic Lake Kivu, eastern Africa. Freshwater Biol. 53: 756-771.

Scanlan DJ, and West NJ. 2002. Molecular ecology of the marine cyanobacterial genera Prochlorococcus and Synechococcus. FEMS Microbiol. Ecol. 40: 1-12.

Stockner J, Callieri C, and Cronberg G. 2000. Picoplankton and other non-bloom forming cyanobacteria in lakes. In: Whitton, B.A., and M. Potts (Eds), The Ecology of Cyano-bacteria. Their Diversity in Time and Space. Kluwer Academic Publishers, Dordrecht, The Netherlands: 195-238.

Stomp M. Huisman J, de Jong F, Veraart AJ, Gerla D, Rijkeboer M, Ibelings BM, Wollenzien UIA, and Stal LJ. 2004. Adaptive divergence in pigment composition promotes phytoplankton biodiversity. Nature 432: 104-107.

ter Braak CJF, and Smilauer P. 2002. CANOCO Reference Manual and CanoDraw for Windows User's guide: Software for Canonical Community Ordination (version 4.5). Microcomputer Power (Ithaca, NY, USA): 500 pp.

Weisse T. 1993. Dynamics of autotrophic picoplankton in marine and freshwater ecosystems. In: Jones, J.G. (Ed.) Advances in Microbial Ecology. 13. Plenum Press, New York: 327-370.

Winder M. 2009. Photosynthetic picoplankton dynamics in Lake Tahoe: temporal and spatial niche partitioning among prokaryotic and eukaryotic cells. J. Plankton Res. 31: 13071320

Zwirglmaier K, Heywood JL, Chamberlain K, Malcolm E, Woodward S, Zubkov MV, Scanlan DJ. 2007. Basinscale distribution patterns of picocyanobacterial lineages in the Atlantic Ocean. Environ. Microbiol. 9: 1278-1290.

Zwirglmaier K, Jardillier L, Ostrowski M, Mazard S, Garczarek L, Vaulot D, Not F, Massana R, Ulloa O, Scanlan DJ. 2008. Global phylogeography of marine Synechococcus and Prochlorococcus reveals a distinct partitioning of lineages among oceanic biomes. Environ. Microbiol. 10: 147-161. 